\section{B 115}

\section{事業所外の従業者支援プログラムの利用者における 精神分裂病を有する勤労者の予測}

伊藤弘人 (日本医科大学医療管理学教室)

藤井堅一郎 (三荾総合研究所)，佐々木雄司(獨協大学)

\section{はじめに}

精神分裂病を有する勤労者は、抗精神病薬の開発によ り、ある程度の生活機能レベルを生かして、勤柔を続け ながら治療とケアを行うことができるようになった。し かし現在でも、いったん退職してしまうと、状態が安定 しても社会復帰の道のりは遠い。この疾患の発病や堌要 時の初期に、この障害の特徽を把握し、適切な支援を行 うことができれば、退職後に待ち受ける困難を軽減でき る可能性がある。本報告では、障害の特盀を初期に把握 する手がかりを明確にするために、䄇神分裂病を有する 勤労者についての從業員支援プログラムの利用パターン の分析を行った。

\section{対重と方法}

対象は、1986年4月から1996年12月までに車業所外の 従業員支援プログラムである財団法人東京影微鏡院ここ ろとからだの相談室に来室した318事例である。平均年鈴 (標準偏差) は35.7(10.7)歳で、男女比はおよそ2:1であ つた。棈神分裂病の診断方法はケース記録を通して、診 断書など主治医による診断または抗辕神病薬の服用を確 認することで行った。本人の性、年齢、精神科受療歴、 所属事業所の設立主体（公私）、初回来室者という、面 接初期に把握できる特徽のうち、どの特徽が精神分裂病 であることを予測できるのかを、単粁集計や判別分析に より検討した。

\section{苦果と若干の考萃}

精神分裂病群は49例（15\%)であり、その他の群は269 例 $(85 \%)$ であった。
精神分㼭病を有する联員の来室パターンを検討するた めに、ステップワイス法による判別分析を行った。ニつ の特㩯が最も2群を判別していた（Wilkis's lambda = 0. $94 ， F=10.6, p<.001)$ 。すなわち精神科受療歴か あり (coefficient $=0.64)$ 、初回相談時点に家族が来室 する場合（同0.79）であり、特に家族の来室の有無がより 強く予測していた。この 2 つの特徽をもとに、分類を行 つた結果が表 1 であり、263事例（82.7\%）が正確に判別 されていた。

表1. 判別分析の結果

\begin{tabular}{|c|c|c|c|}
\hline & 精神分裂病 & その他 & 計 \\
\hline 選択されたパ & 13 & 19 & 32 \\
ターン(注) & $(40.6 \%)$ & $(59.4 \%)$ & $(100 \%)$ \\
\hline 他のパターン & 36 & 250 & 286 \\
& $(12.6 \%)$ & $(87.4 \%)$ & $(100 \%)$ \\
\hline 合計 & 49 & 269 & 318 \\
& $(15.4)$ & $(84.6 \%)$ & $(100 \%)$ \\
\hline
\end{tabular}

（注）棈神科受療歴があり、初回に家族が来室した相談

事業所外の従業員支援プログラムに利用者ですでに精 神科受療歴があり、初回に家族が来室する相談の場合の 4 割程度が、精神分裂病を有する勤労者の相談であった。 この群は、精神科医療をすでに受け、日常生活に障害を 有するために家族も問題を認識して、来室に至ったと考 えられる。

今回の結果は、この来室パターンであれば必ず精神分 翌病であることを意味してはいない。しかしそれ以外の パターンに比較してこの障害を有している確率が高いた め、その可能性を十分検討しながら支援する必要がある ことを示している。 